\title{
Studi Penentuan Status Mutu Air Menggunakan Metode Indeks Pencemaran Dan WQI Di Tukad Badung, Denpasar
}

Study of Water Quality Status Determination Using Pollution Index and WQI Methods in Tukad Badung, Denpasar

\author{
Made Dimas Permata Gupta ${ }^{1 *}$, Riyanto Haribowo ${ }^{1}$, Tri Budi Prayogo ${ }^{1}$ \\ ${ }^{1}$ Jurusan Teknik Pengairan, Fakultas Teknik, Universitas Brawijaya, Malang, Indonesia
}

Article info:

Kata kunci:

Indeks Pencemaran, kualitas air, simulasi industri, water quality index (WQI)

Keywords:

industry simulation, pollution index, water quality index (WQI), water quality

\section{Article history:}

Received: 21-09-2020

Accepted: 27-11-2020

${ }^{*}$ Koresponden email: dimaspermata86@gmail.com

\begin{abstract}
Abstrak
Berkembangnya pertumbuhan penduduk secara pesat membuat keberadaan sumber daya air yang tersedia meliputi kualitas air menurun. Selain itu dipengaruhi juga oleh adanya perubahan tata guna lahan yang dulunya ruang terbuka hijau menjadi daerah pemukiman dan industri. Analisis dilakukan untuk mengetahui kualitas air Tukad Badung tahun 2012-2020. Data yang digunakan didapatkan dari Balai Wilayah Sungai Bali Penida dengan lima titik pemantauan kualitas air yang akan dianalisis dengan menggunakan metode Indeks Pencemaran (IP) dan Water Quality Index (WQI). Lalu setelah mendapatkan nilai indeks kualitas airnya, akan dilakukan simulasi industri dengan menggunakan data industri dan data nilai indeks kualitas air. Parameter yang digunakan dalam penelitian ini meliputi BOD, COD, DO, suhu, pH, TSS, Kadmium $(\mathrm{Cd})$, Seng ( $\mathrm{Zn})$, Tembaga (Cu), Kromium (Cr), Timbal ( $\mathrm{Pb})$, Bakteri E.Coli, Bakteri Coliform, Nitrat $\left(\mathrm{NO}_{3}^{-}\right)$, Nitrit $\left(\mathrm{NO}_{2}^{-}\right)$, Phospat $\left(\mathrm{PO}_{4}{ }^{3-}\right)$. Hasil analisis pada tahun 2020 dengan menggunakan metode Indeks Pencemaran mendapatkan hasil $100 \%$ dalam kondisi tercemar ringan. Sedangkan hasil pada metode WQI mendapatkan hasil $100 \%$ adalah tercemar ringan. Hasil simulasi industri I dan II tidak jauh berbeda karena nilai indeks kualitas airnya tidak jauh berbeda.
\end{abstract}

\begin{abstract}
Rapid population growth has made the availability of available water resources, including water quality degradation. In addition, it is also influenced by changes in land use from previously green open spaces to residential and industrial areas. Analysis was carried out to determine the quality of Tukad Badung water based on 2012-2020 data. The data used were obtained from Bali Penida River Basin with five water quality monitoring points which will be analyzed using the Pollution Index (IP) and Water Quality Index (WQI). Then, after getting the water quality index value, and industrial simulation will be carried out using industry data and the water quality index value data. The parameters used in this study include BOD, COD, DO, Temperature, $\mathrm{pH}$, TSS, Cadmium (Cd), Lead ( $\mathrm{Pb})$, E.Coli bacteria, Bacteria Coliform, Nitrate $\left(\mathrm{NO}_{3}{ }^{-}\right)$, Nitrite $\left(\mathrm{NO}_{2}{ }^{-}\right)$, Phosphate $\left(\mathrm{PO}_{4}{ }^{3}\right)$. The results of analysis in 2020 using the Pollution Index method, get $100 \%$ results in lightly polluted conditions. While the results in the WQI method get $100 \%$ results that are lightly polluted. The results of industrial simulation I and II are not much different because the water quality index value is not much different.
\end{abstract}




\section{Pendahuluan}

Air merupakan bahan alam yang diperlukan untuk kehidupan manusia, hewan dan tanaman yaitu sebagai media pengangkutan berbagai zat makanan dan juga merupakan sumber energi serta berbagai keperluan lainnya (Arsyad 1989 dalam Sasongko, Widyastuti, and Priyono 2014).

Berdasarkan Peraturan Pemerintah Republik Indonesia Nomor 38 Tahun 2011 tentang sungai, dijelaskan bahwa sungai adalah alur atau wadah air alami dan/buatan berupa jaringan pengaliran air beserta air di dalamnya, mulai dari hulu sampai muara dengan dibatasi kanan dan kiri oleh garis sempadan (Haribowo, Dermawan, and Yudha 2018).

Pada keadaannya, air bersih di muka bumi semakin hari semakin berkurang. Kemudian bermunculan pencemaran terjadi pada air bersih (Yamashita et al. 2012). Pada zaman sekarang, tingkat pencemaran air semakin meningkat diiringi dengan perkembangan industri yang pesat sehingga menyebabkan penggunaan air bersih di muka bumi menjadi tidak seimbang (Hadisantoso et al. 2018; Haribowo et al. 2017).

Tukad Badung adalah salah satu sungai yang mengalir dan memasuki Kota Denpasar setelah mengalir dari Kabupaten Badung. Keberadaan sungai ini sangat bermanfaat bagi kebutuhan hidup manusia dan sebagai lingkungan akuatik bagi makhluk hidup yang ada di sekitarnya, selain itu berfungsi sebagai mengalirkan air hujan menuju ke laut. Tukad Badung juga digunakan sebagai tempat pembuangan baik itu limbah tapioka, limbah peternakan maupun limbah rumah tangga (Mahendra et al. 2015).

Permasalahan yang dihadapi di Tukad Badung sekarang yaitu pada titik lokasi pemantauan kualitas air terdapat kualitas air yang tergolong tercemar. Pada tahun 2019 terdapat berita yang dilansir oleh Bali Tribunnews bahwa sebanyak 31 titik sungai di Denpasar, salah satunya Tukad Badung yang dicek oleh Dinas Lingkungan Hidup dan Kebersihan (DLHK) Kota Denpasar dan memberi hasil bahwa semua sungai di Denpasar masuk kategori tercemar ringan.

Tujuan dari studi ini adalah mengetahui nilai indeks kualitas air di Tukad Badung berdasarkan metode Indeks Pencemaran dan Water Quality Index, mengetahui sebaran kualitas air di Tukad Badung dan melakukan simulasi industri berdasarkan nilai indeks kualitas air.

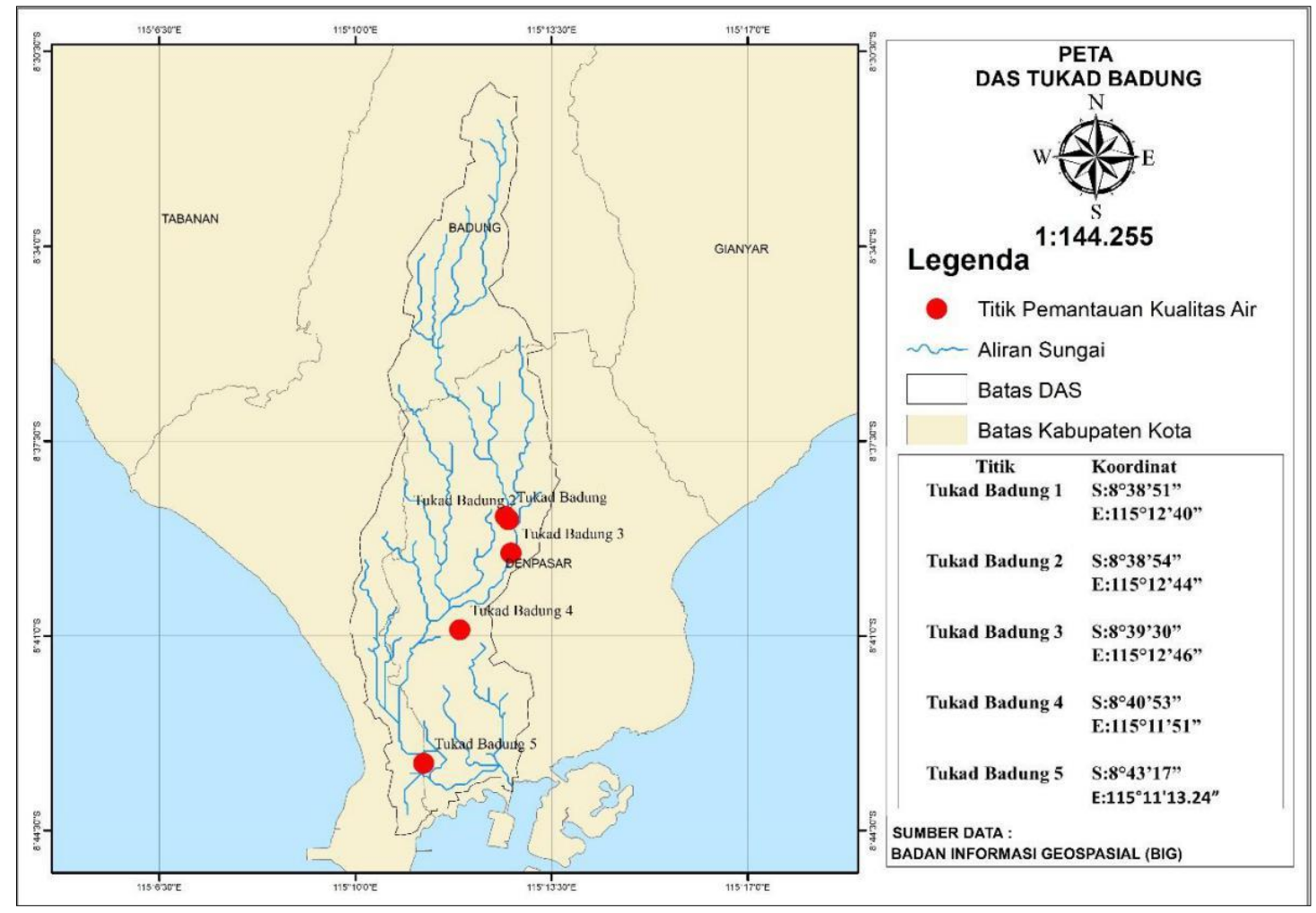

Gambar 1. Peta DAS Tukad Badung 


\section{Bahan dan Metode}

\subsection{Gambaran umum lokasi studi}

Tukad Badung terletak di Kota Denpasar, Provinsi Bali. Secara umum Tukad Badung dibagi menjadi 3 bagian yaitu bagian hulu, tengah, dan hilir. Daerah hulu berlokasi di daerah Ubung. Daerah tengah berlokasi di Jalan Hasanuddin, Denpasar. Daerah hilir berlokasi di estuary dam, Pemogan. Luas daerah aliran sungai adalah $91 \mathrm{~km}^{2}$ dengan panjang sungai utama $\pm 33 \mathrm{~km}$ (Gambar 1).

\subsection{Pengumpulan data-data studi}

Pengumpulan data-data dalam studi tentang studi penentuan status mutu air dengan menggunakan metode Indeks Pencemaran dan Water Quality Index (WQI) di Tukad Badung, Denpasar dilakukan secara sekunder dengan data sebagai berikut :

1. Data kualitas air Tukad Badung Tahun 2012-2020

2. Peta topografi dan Data Elevation Model (DEM) Tukad Badung

3. Peta Rupa Bumi Indonesia (RBI) di Denpasar, Bali

4. Data industri di sekitar Tukad Badung tahun 2019

\subsection{Langkah pengerjaan}

Proses pengerjaan analisis pada studi ini dikelompokkan menjadi tiga, yaitu analisis statistika terhadap data kualitas air Tukad Badung, perhitungan beserta analisis dari tiap metode lalu simulasi industri. Setelah itu akan ditampilkan melalui teknologi Sistem Informasi Geografis dengan Aplikasi ArcGis.

a. Analisis statistika terhadap data kualitas air

Analisis statistika yang digunakan adalah uji stasioner yakni uji ANOVA dan uji-t. Uji ANOVA bertujuan untuk menghitung nilai $F$. Lalu nilai $F$ tersebut akan dibandingkan dengan nilai $F$ kritis (Fcr) dari tabel F (Limantara and Soetopo 2014). Uji-t bertujuan untuk menguji kestabilan nilai rerata (Soewarno 1995).

b. Perhitungan dan analisis tiap metode

Melakukan perhitungan dan analisis dengan menggunakan metode Indeks Pencemaran dan Water Quality Index (WQI) dengan menggunakan baku mutu menurut Peraturan Gubernur Bali Nomor 16 Tahun 2016 tentang Baku Mutu Lingkungan Hidup dan Kriteria Baku Kerusakan Lingkungan Hidup. Perhitungan status mutu air menggunakan dua metode, yaitu metode Indeks Pencemaran (Keputusan Menteri Negara Lingkungan Hidup 2003) dan metode Water Quality Index (Altansukh and Davaa 2011).

c. Simulasi industri

Simulasi industri dilakukan dengan cara matematika sederhana yaitu perkalian silang satu variabel, di mana dengan menggunakan cara tersebut dapat mengetahui nilai variabel yang tidak diketahui.

d. Tampilan hasil melalui program ArcGis

Setelah 3 tahap diatas telah dilakukan, maka langkah terakhir yaitu menampilkan hasil petanya melalui program ArcGis. Dengan menggunakan metode Kriging/IDW. Metode Kriging adalah metode estimasi stokastik yang hampir sama dengan metode IDW di mana memakai kombinasi linear dari weight untuk memperkirakan nilai yang berada di antara sampel data $(C$ Tech Development Corporation 2004 dalam Pramono 2008). Metode IDW adalah metode deterministik yang bersifat sederhana dengan mempertimbangkan titik yang berada di sekitarnya (NCGIA 1997 dalam Pramono 2008).

\section{Hasil dan Pembahasan}

\subsection{Uji ANOVA}

Dengan menggunakan rumus sebagai berikut

$$
F B O D=\frac{(n-k) \cdot \sum_{i=1}^{k} n 1(\overline{X l}-\bar{X})^{2}}{(n-k) \cdot=\sum_{i-1}^{k} \cdot \sum_{i=1}^{k} n 1(\overline{X \iota}-\bar{X})^{2}}
$$


Sehingga didapatkan hasil uji ANOVA pada Tabel 1 untuk parameter yang digunakan dalam penelitian ini sebagai berikut

Tabel 1. Hasil perhitungan uji ANOVA

\begin{tabular}{lccc}
\hline Parameter & Nilai F & Fcr & Sifat \\
\hline BOD & 0.251 & 5.72 & Homogen \\
\hline COD & 0.083 & 5.72 & Homogen \\
\hline DO & 0.184 & 5.72 & Homogen \\
\hline Suhu & 0.146 & 5.72 & Homogen \\
\hline pH & 0.379 & 5.72 & Homogen \\
\hline P04 & 0.144 & 5.72 & Homogen \\
\hline TSS & 0.065 & 5.72 & Homogen \\
\hline E.Coli & 0.042 & 5.72 & Homogen \\
\hline Coliform & 0.257 & 5.72 & Homogen \\
\hline Kadmium & 0.826 & 5.72 & Homogen \\
\hline Kromium & 0.510 & 5.72 & Homogen \\
\hline Tembaga & 0.010 & 5.72 & Homogen \\
\hline Timbal & 0.088 & 5.72 & Homogen \\
\hline Seng & 2.474 & 5.72 & Homogen \\
\hline Nitrat & 0.676 & 5.72 & Homogen \\
\hline Nitrit & 0.010 & 5.72 & Homogen \\
\hline
\end{tabular}

Jadi uji analisis variansi mendapatkan hasil bahwa seluruh parameter kualitas air di DAS Tukad Badung adalah homogen.

\subsubsection{Uji-t}

Berikut merupakan contoh perhitungan uji-t pada Tukad Badung 1.

$$
\begin{aligned}
& \sigma=\left(\frac{N_{1} S_{1}{ }^{2}+N_{2} S_{2}{ }^{2}}{N_{1}+N_{2}-2}\right)^{0.5} \\
& \text { thitung }=\frac{\left|\left(X_{1}-X_{2}\right)\right|}{\sigma\left(\frac{1}{N_{1}}+\frac{1}{N_{2}}\right)^{0.5}}
\end{aligned}
$$

Didapatkan bahwa nilai $t_{\text {hitung }}$ sebesar $3.228<\mathrm{t}_{\text {tabel }}$ sebesar 3.499 dengan derajat kepercayaan 0.005 , maka hipotesa diterima dan data dinyatakan stasioner. Untuk hasil perhitungan uji-t pada Tukad Badung 1 - Tukad Badung 5 disajikan pada Tabel 2.

Tabel 2. Hasil uji-t terhadap parameter BOD

\begin{tabular}{cccccc}
\hline Rekapitulasi & \multicolumn{5}{c}{ Titik } \\
\cline { 2 - 6 } & Tk.Badung & Tk.Badung & Tk.Badung & Tk.Badung & Tk.Badung \\
& 1 & 2 & 3 & 4 & 5 \\
\hline $\mathrm{t}_{\text {hitung }}$ & 3.228 & 3.295 & 2.208 & 2.854 & 2.841 \\
\hline $\mathrm{t}_{\text {tabel }}$ & 3.499 & 3.449 & 3.449 & 3.449 & 3.449 \\
\hline kesimpulan & diterima & diterima & diterima & diterima & diterima \\
\hline
\end{tabular}




\subsection{Metode Indeks Pencemaran}

Menurut metode Indeks Pencemaran, nilai indeks kualitas air tidak menunjukkan perubahan secara signifikan dari tahun 2012 hingga tahun 2021 di titik Tukad Badung 1 - Tukad Badung 5. Hasil dari metode Indeks Pencemaran disajikan pada Gambar 2.

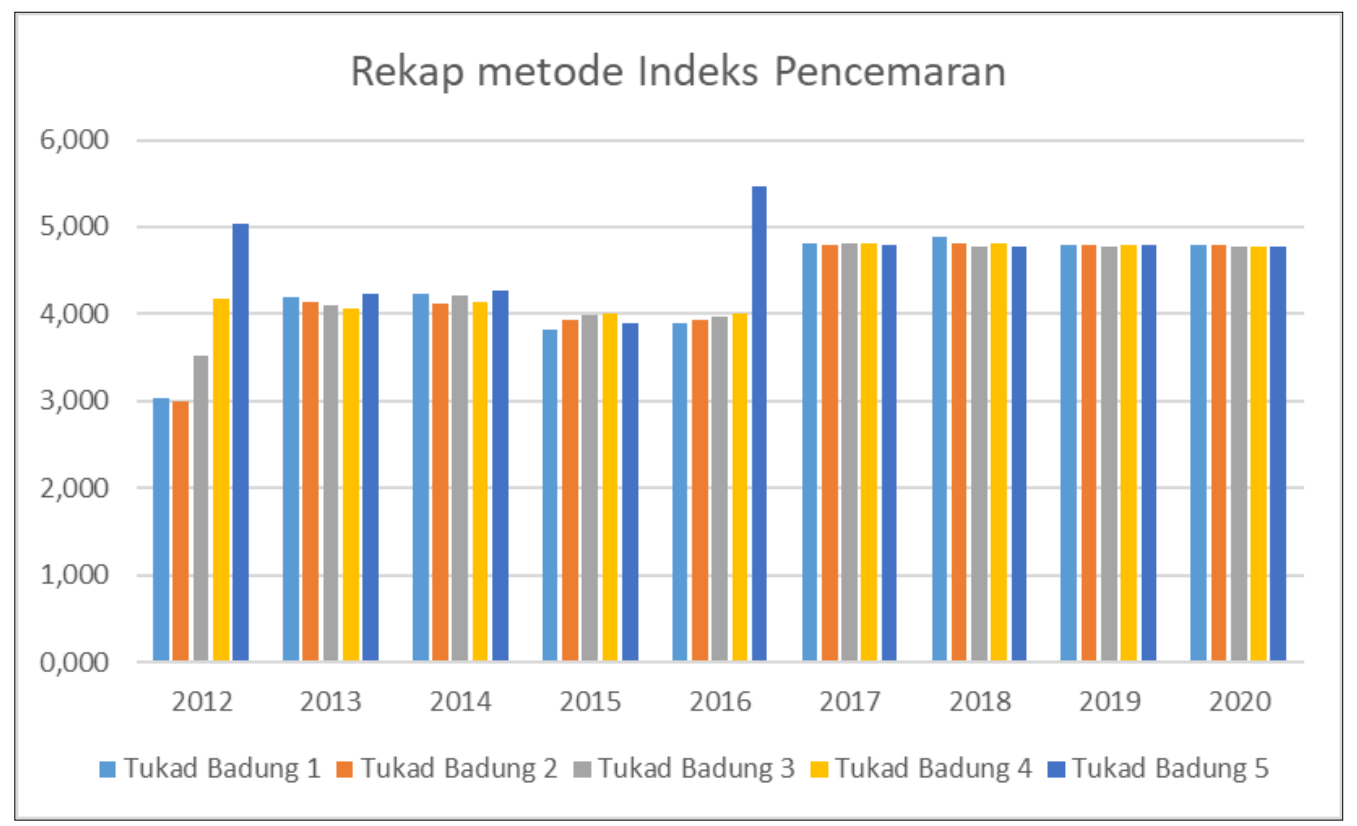

Gambar 2. Rekapitulasi nilai Indeks Pencemaran di Tukad Badung

Pada Gambar 2, terlihat bahwa pada tahun 2012-2014 nilai indeks kualitas air mengalami kenaikan, seperti contohnya pada tahun 2012 ke tahun 2013 pada titik Tukad Badung 1, dimana pada tahun 2012 mendapatkan nilai sebesar 3.041 lalu meningkat menjadi 4.188 pada tahun 2013 meskipun nilai tersebut masih berada dalam kelas yang sama yakni tercemar ringan. Lalu pada tahun 2014 menuju tahun 2015 mengalami penurunan. Dari tahun 2015 ke tahun 2018 mengalami kenaikan. Tahun 2018 menuju tahun 2019 mengalami penurunan dan pada tahun 2020 nilainya sama dengan nilai tahun 2019.

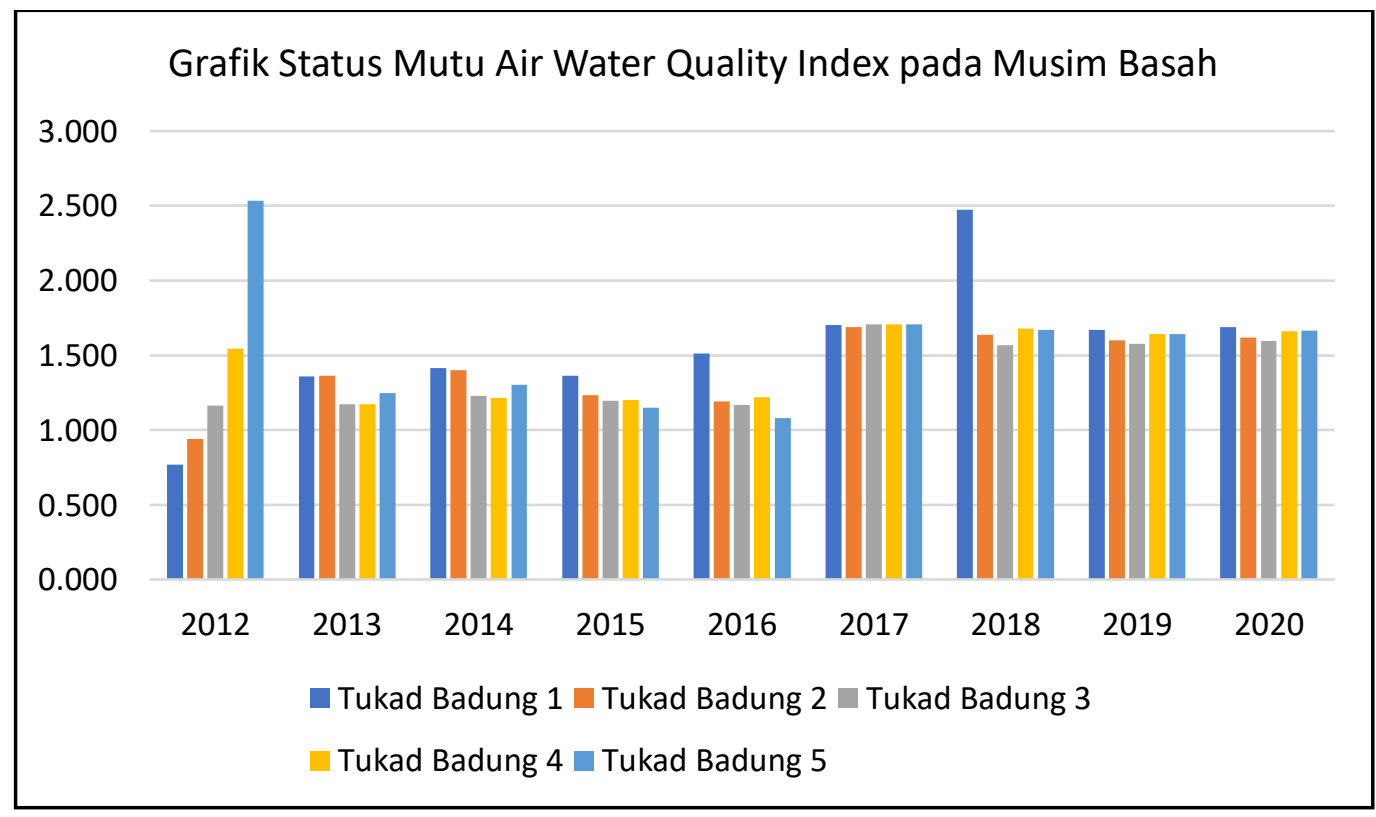

Gambar 3. Rekapitulasi nilai Water Quality Index di Tukad Badung 


\subsubsection{Metode Water Quality Index}

Menurut metode Water Quality Index, nilai indeks kualitas air terjadi perubahan namun tidak begitu signifikan perubahan secara signifikan dari tahun 2012 hingga tahun 2020 di titik Tukad Badung 1 - Tukad Badung 5. Hasil dari metode WQI disajikan pada Gambar 3.

Pada Gambar 3, terlihat bahwa terjadi perubahan namun tidak begitu signifikan dari tahun ke tahun pada kelima titik pemantauan kualitas air DAS Tukad Badung. Seperti contohnya pada titik Tukad Badung 1, pada tahun 2012 mendapatkan nilai WQI sebesar 0.769 dengan keterangan bersih lalu meningkat pada tahun 2013 dan 2014 sebesar 1.359 dan 1.413 dengan keterangan tercemar ringan. Lalu mengalami penurunan pada tahun 2015 menjadi 1.365 dengan keterangan tercemar ringan. Lalu hingga ke 2018 mengalami peningkatan di mana nilainya menjadi 2.472 dengan keterangan tercemar sedang dan mengalami penurunan pada Tahun 2019 dan mengalami peningkatan pada Tahun 2020.

\subsubsection{Analisis catchment DAS}

Analisis catchment DAS dilakukan dengan membandingkan nilai indeks kualitas air terhadap baku mutu yang diijinkan. Dari Gambar 4, dapat dilihat bahwa nilai parameter fosfat pada titik Tukad Badung 1 dari tahun 2012 hingga tahun 2020 melebihi baku mutu yang telah ditentukan. Hal tersebut menandakan bahwa pada titik Tukad Badung 1 tercemar oleh parameter fosfat. Fosfat dalam perairan sangat dipengaruhi oleh aktivitas manusia di darat terutama kegiatan penggunaan pupuk pada perkebunan dan pertanian.

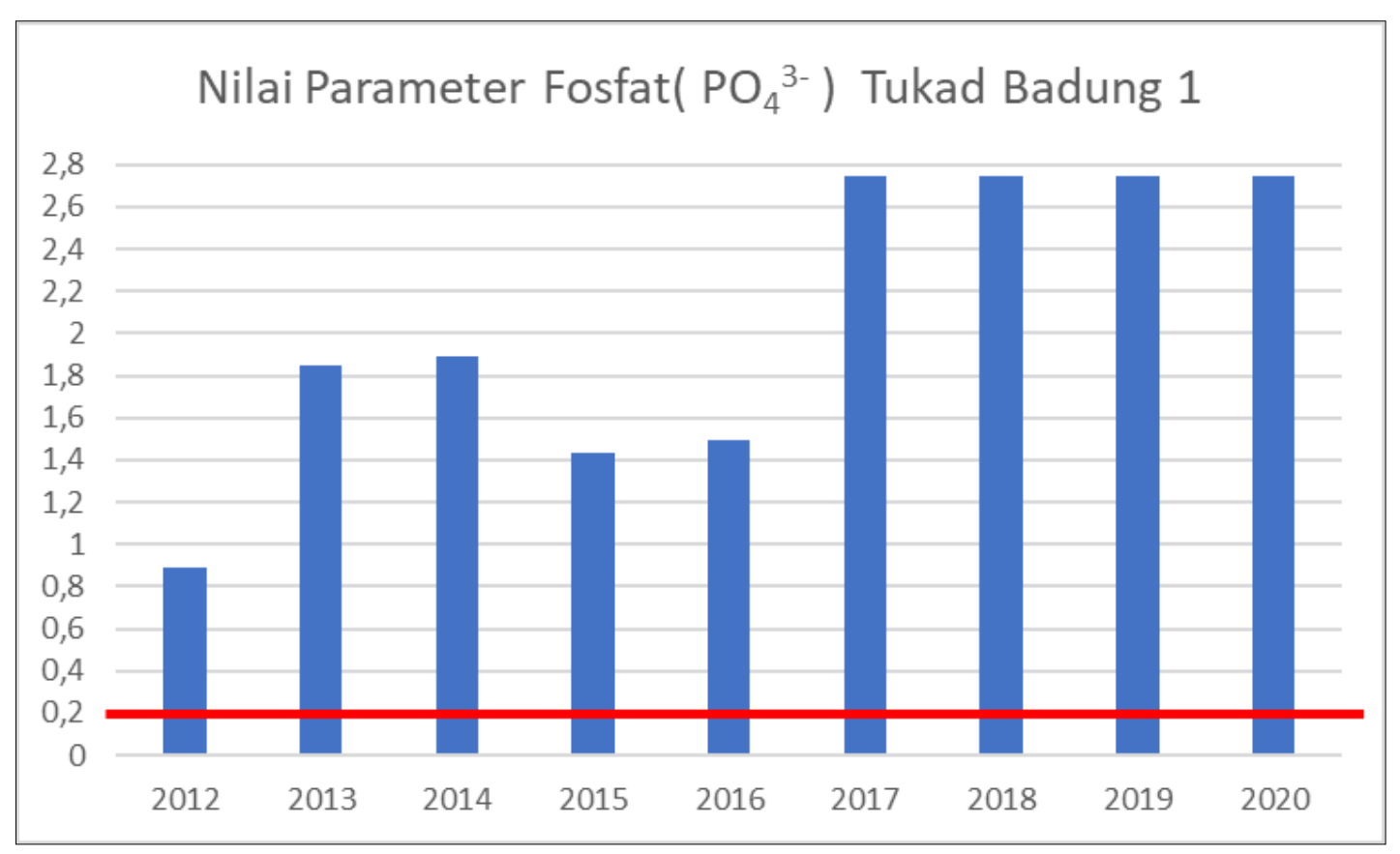

Gambar 4. Nilai parameter Fosfat Tukad Badung 1

\subsection{Simulasi Industri}

Simulasi Industri yang dilakukan dalam penelitian ini terdapat dua simulasi. Yakni simulasi I dan simulasi II. Simulasi I adalah simulasi dimana kondisi menggunakan indeks kualitas air metode Indeks Pencemaran dan Water Quality Index (WQI) Tahun 2019 dan data jumlah industri eksisting pada Tahun 2019 yang. Simulasi II adalah simulasi dimana kondisi menggunakan indeks kualitas air metode Indeks Pencemaran dan Water Quality Index I (WQI) Tahun 2020 dan data jumlah industri eksisting pada Tahun 2019 dimana data indeks kualitas air bersumber dari Balai Wilayah Sungai Bali Penida (BWS Bali Penida) dan data jumlah industri bersumber dari Dinas Lingkungan Hidup dan Kebersihan Kota Denpasar. Adapun tujuan menggunakan dua simulasi untuk melihat apakah dengan jumlah industri yang sama namun nilai indeks kualitas air yang berbeda akan menghasilkan hasil yang sama atau berbeda. 
Berikut hasil simulasi industri dengan menggunakan rumus berikut.

$$
x=\frac{\text { nilai indeks kualitas air } x \text { jumlah industri yang akan ditambah/dikurang }}{\text { jumlah industri eksisting }}
$$

Dengan demikian yang menjadi batas minimal industri yang diijinkan pada tiap titik adalah di mana saat nilai indeks kualitas airnya kelas paling atas dan yang menjadi batas maksimal industri adalah kelas paling bawah.

Tabel 3. Rekapitulasi jumlah industri metode WQI hasil simulasi I dan II

\begin{tabular}{lcccccc}
\hline & Simulasi I & & \multicolumn{4}{c}{ Simulasi II } \\
\hline Titik & Eksisting & Min & Max & Eksisting & Min & Max \\
\hline Tukad Badung 1 & 471 & 87 & 1694 & 471 & 86 & 1674 \\
\hline Tukad Badung 2 & 471 & 91 & 1768 & 471 & 90 & 1747 \\
\hline Tukad Badung 3 & 92 & 17 & 350 & 92 & 17 & 346 \\
\hline Tukad Badung 4 & 200 & 37 & 730 & 200 & 37 & 721 \\
\hline Tukad Badung 5 & 267 & 49 & 960 & 267 & 49 & 962 \\
\hline
\end{tabular}

Data jumlah industri eksisting pada Tabel 3 bersumber dari Dinas Lingkungan Hidup dan Kebersihan Kota Denpasar, sedangkan jumlah minimal dan maksimal industri adalah hasil dari simulasi. Jumlah minimal industri pada saat nilai indeks kualitas airnya kelas paling atas dan yang menjadi batas maksimal industri adalah kelas paling bawah. Pada Tabel 3 terlihat hasil simulasi berupa jumlah minimal industri dan maksimal industri Metode WQI pada wilayah sekitar DAS Tukad Badung tidak jauh berbeda karena dapat dilihat pada Tabel 5 yaitu nilai indeks metode WQI Simulasi I dan II tidak jauh berbeda. Karena menggunakan operasi matematika sederhana yaitu kali silang maka hasil jumlah industrinya pun tidak jauh berbeda juga.

Tabel 4. Rekapitulasi jumlah industri metode Indeks Pencemaran hasil simulasi I dan II

\begin{tabular}{lcccccc}
\hline & Simulasi I & & \multicolumn{3}{c}{ Simulasi II } \\
\hline Titik & Eksisting & Min & Max & Eksisting & Min & Max \\
\hline Tukad Badung 1 & 471 & 98 & 981 & 471 & 98 & 981 \\
\hline Tukad Badung 2 & 471 & 98 & 984 & 471 & 98 & 984 \\
\hline Tukad Badung 3 & 92 & 19 & 192 & 92 & 19 & 193 \\
\hline Tukad Badung 4 & 200 & 41 & 418 & 200 & 41 & 418 \\
\hline Tukad Badung 5 & 267 & 55 & 558 & 267 & 55 & 558 \\
\hline
\end{tabular}

Jumlah minimal industri pada saat nilai indeks kualitas airnya kelas paling atas dan yang menjadi batas maksimal industri adalah kelas paling bawah. Pada Tabel 4 terlihat hasil simulasi berupa jumlah minimal industri dan maksimal industri Metode Indeks Pencemaran pada wilayah sekitar DAS Tukad Badung tidak jauh berbeda. Pada Tabel 6 nilai indeks metode Indeks Pencemaran Simulasi I dan II jauh berbeda. Karena menggunakan operasi matematika sederhana yaitu kali silang maka hasil jumlah industrinya pun tidak jauh berbeda juga.

Tabel 5. Rekapitulasi nilai indeks metode WQI hasil simulasi I dan II

\begin{tabular}{lcccccc}
\hline & Simulasi I & & \multicolumn{4}{c}{ Simulasi II } \\
\hline Titik & Eksisting & Min & Max & Eksisting & Min & Max \\
\hline Tukad Badung 1 & 1.668 & 0.308 & 5.999 & 1.688 & 0.301 & 5.998 \\
\hline Tukad Badung 2 & 1.598 & 0.309 & 5.998 & 1.617 & 0.302 & 5.999 \\
\hline Tukad Badung 3 & 1.575 & 0.291 & 5.993 & 1.595 & 0.295 & 5.999 \\
\hline Tukad Badung 4 & 1.643 & 0.304 & 5.997 & 1.662 & 0.308 & 5.993 \\
\hline Tukad Badung 5 & 1.668 & 0.300 & 5.996 & 1.664 & 0.305 & 5.994 \\
\hline
\end{tabular}


Data eksisting nilai indeks kualitas air pada Tabel 5 didapatkan dari hasil perhitungan metode WQI dari data kualitas air yang bersumber dari Balai Wilayah Sungai Bali Penida. Sedangkan jumlah minimal dan maksimal industri dicoba-coba hingga mendapatkan hasil dengan ketentuan batas minimal industri yang diijinkan pada tiap titik adalah pada saat nilai indeks kualitas airnya kelas paling atas dan yang menjadi batas maksimal industri

Tabel 6. Rekapitulasi nilai indeks metode Indeks Pencemaran hasil simulasi I dan II

\begin{tabular}{ccccccc}
\hline \multicolumn{2}{c}{ Simulasi I } & & \multicolumn{3}{c}{ Simulasi II } \\
\hline Titik & Eksisting & Min & Max & Eksisting & Min & Max \\
\hline Tukad Badung 1 & 4.800 & 0.999 & 9.997 & 4.799 & 0.998 & 9.995 \\
\hline Tukad Badung 2 & 4.786 & 0.996 & 9.999 & 4.782 & 0.995 & 9.991 \\
\hline Tukad Badung 3 & 4.768 & 0.985 & 9.951 & 4.764 & 0.984 & 9.994 \\
\hline Tukad Badung 4 & 4.784 & 0.981 & 9.999 & 4.779 & 0.980 & 9.988 \\
\hline Tukad Badung 5 & 4.784 & 0.985 & 9.998 & 4.780 & 0.985 & 9.989 \\
\hline
\end{tabular}

Data eksisting nilai indeks kualitas air pada Tabel 6 didapatkan dari hasil perhitungan metode Indeks Pencemaran dari data kualitas air yang bersumber dari Balai Wilayah Sungai Bali Penida. Sedangkan jumlah minimal dan maksimal industri dicoba-coba hingga mendapatkan hasil dengan ketentuan batas minimal industri yang diijinkan pada tiap titik adalah pada saat nilai indeks kualitas airnya kelas paling atas dan yang menjadi batas maksimal industri.

\subsection{Tampilan hasil melalui Program ArcGis}

Dengan menggunakan data indeks kualitas air dan data koordinat titik pemantauan kualitas air dapat dipetakan sebaran kualitas airnya melalui metode Kriging. Berikut adalah tampilan hasil dengan menggunakan metode Kriging melalui program ArcGis. Dari metode Kriging menghasilkan sebaran kualitas air pada kelima titik pemantauan kualitas air pada kondisi eksisting menggunakan metode Water Quality Index (WQI) dengan nilai sebesar 1.575 - 1.688 di mana termasuk kategori tercemar ringan dengan jumlah industri sebanyak total 1030 industri (Gambar 5).

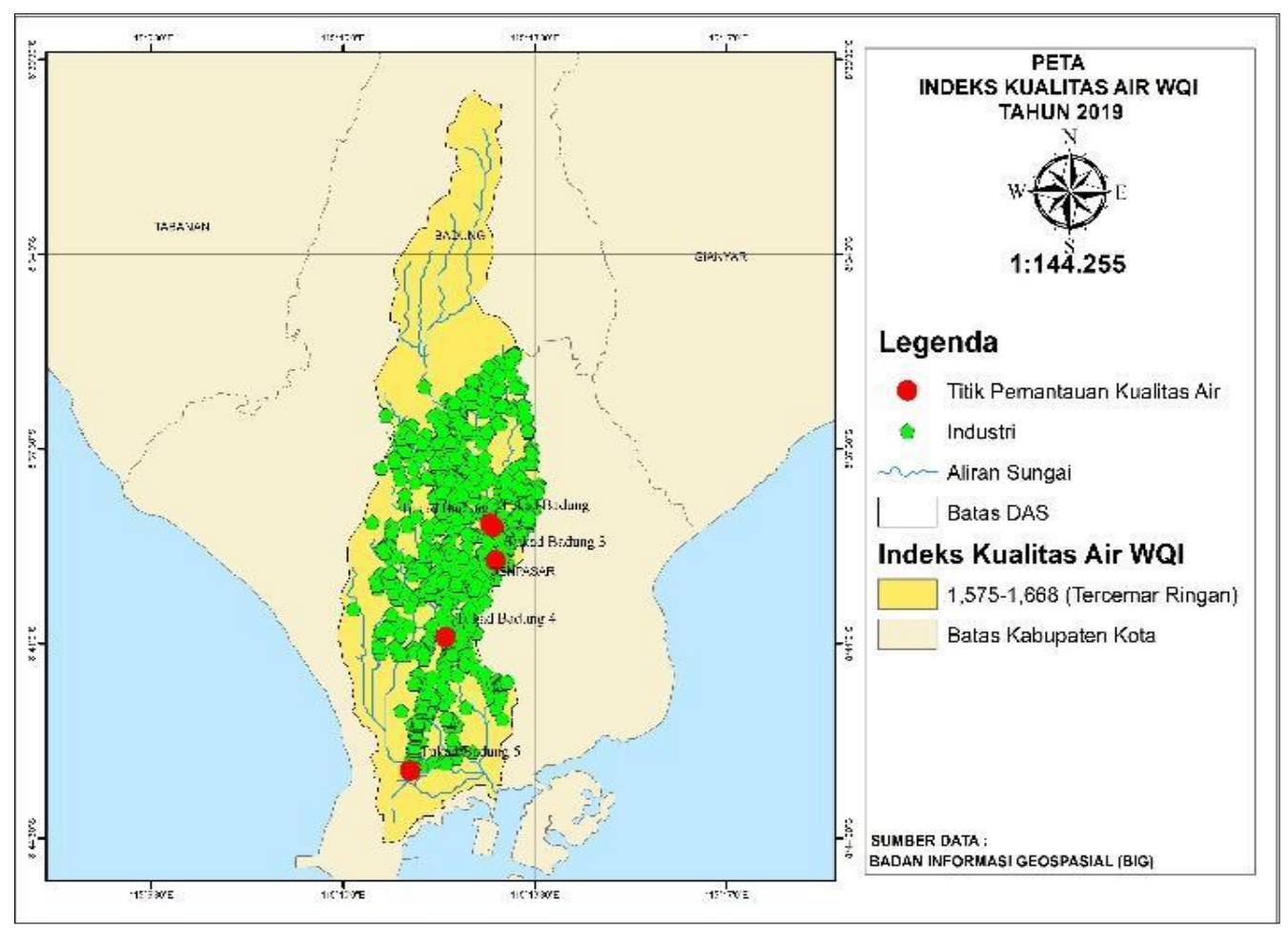

Gambar 5. Pemetaan sebaran kualitas air eksisting simulasi 1 metode WQI tahun 2019 


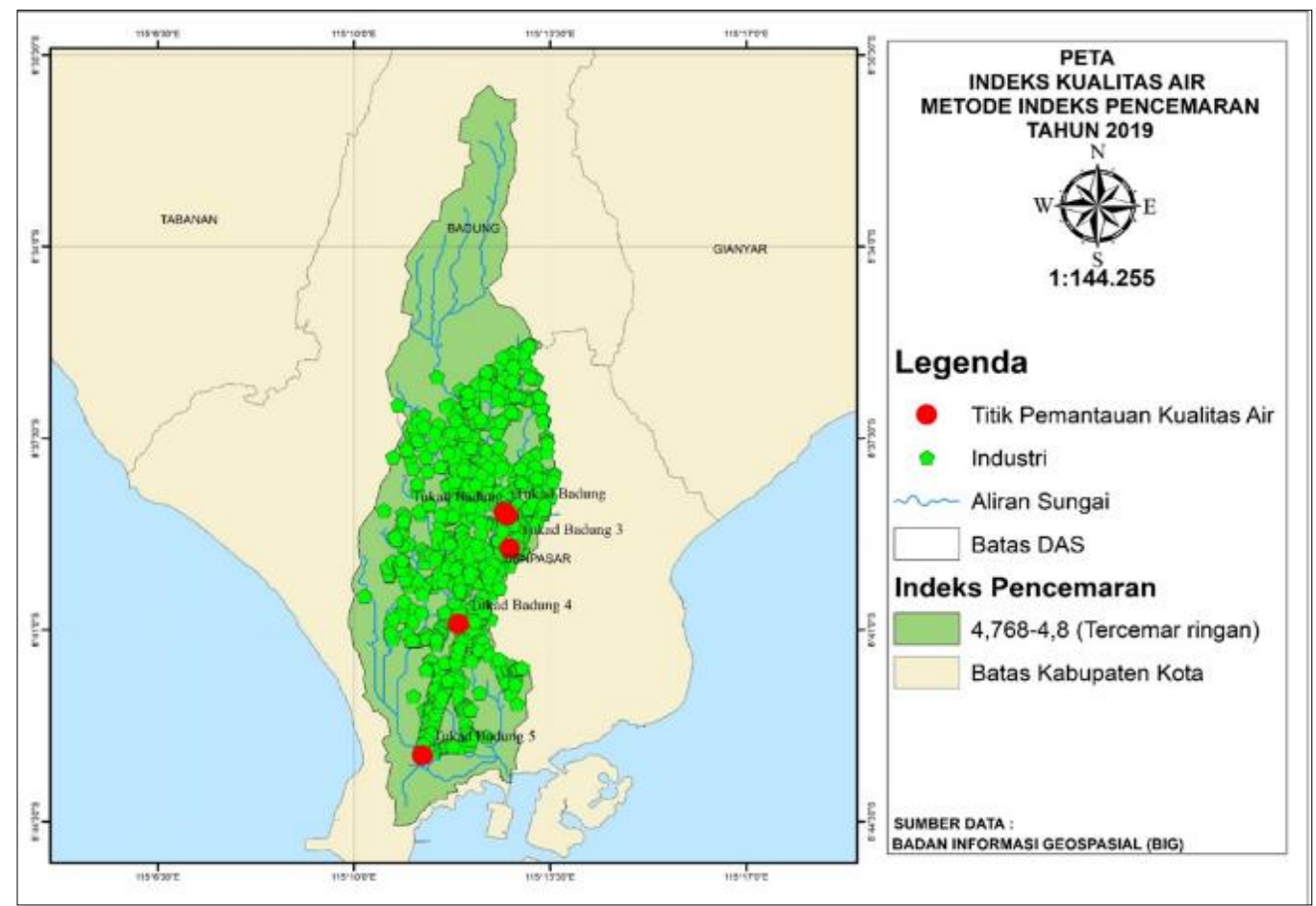

Gambar 6. Pemetaan sebaran kualitas air eksisting simulasi 1 metode IP tahun 2019

Pada Gambar 6 disajikan hasil dari metode Kriging yang menghasilkan sebaran kualitas air pada kelima titik pemantauan kualitas air pada kondisi eksisting menggunakan metode Indeks Pencemaran dengan nilai sebesar 4.768-4.8 di mana termasuk kategori tercemar ringan dengan jumlah industri sebanyak total 1030 industri.

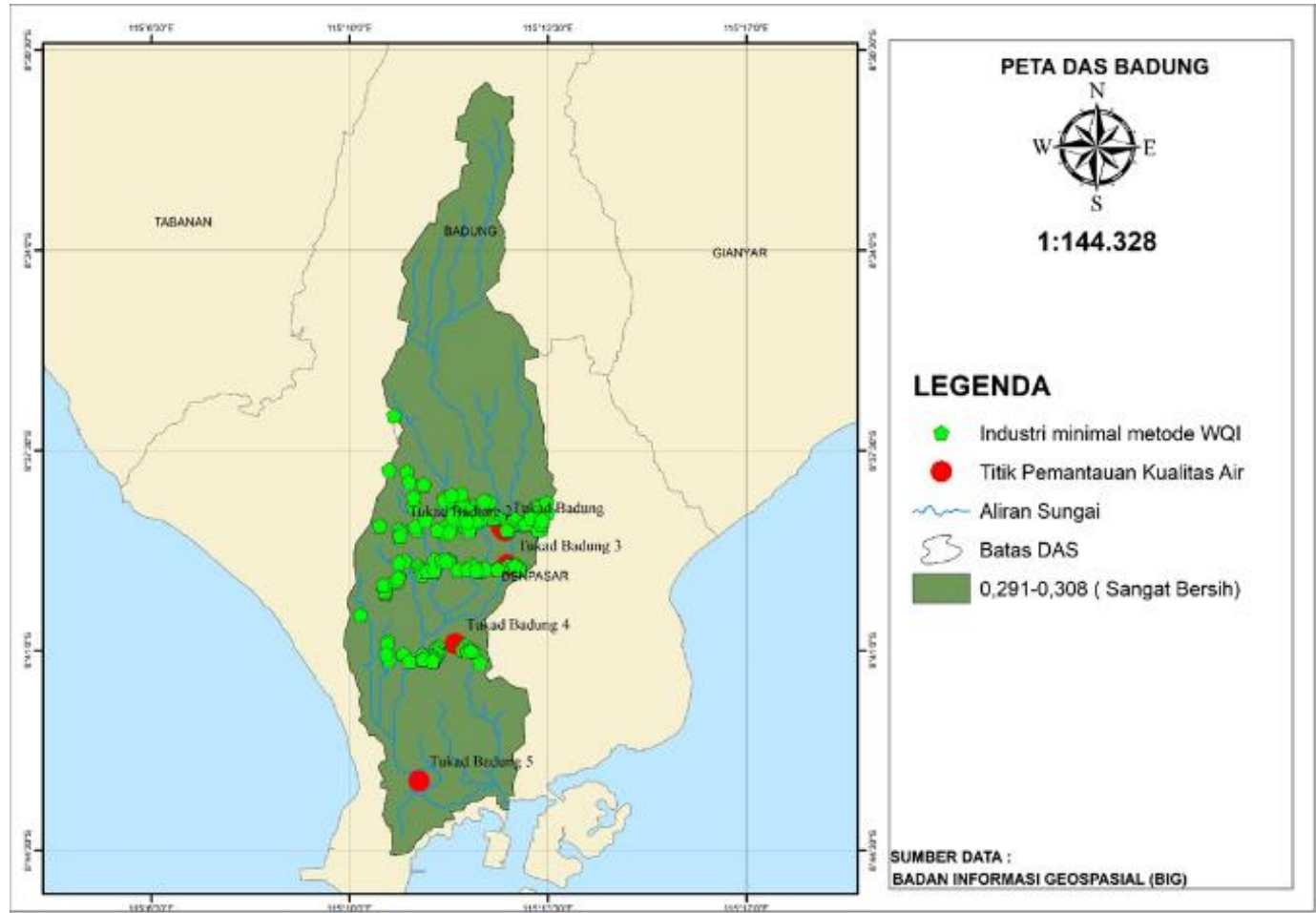

Gambar 7. Pemetaan sebaran kualitas air minimal simulasi 1 metode WQI tahun 2019 
Pada Gambar 7 disajikan hasil dari metode Kriging yang menghasilkan sebaran kualitas air pada kelima titik pemantauan kualitas air pada kondisi minimal menggunakan metode Water Quality Index (WQI) dengan nilai sebesar $0.291-0.308$ di mana termasuk kategori sangat bersih dengan jumlah industri sebanyak total 190 industri.

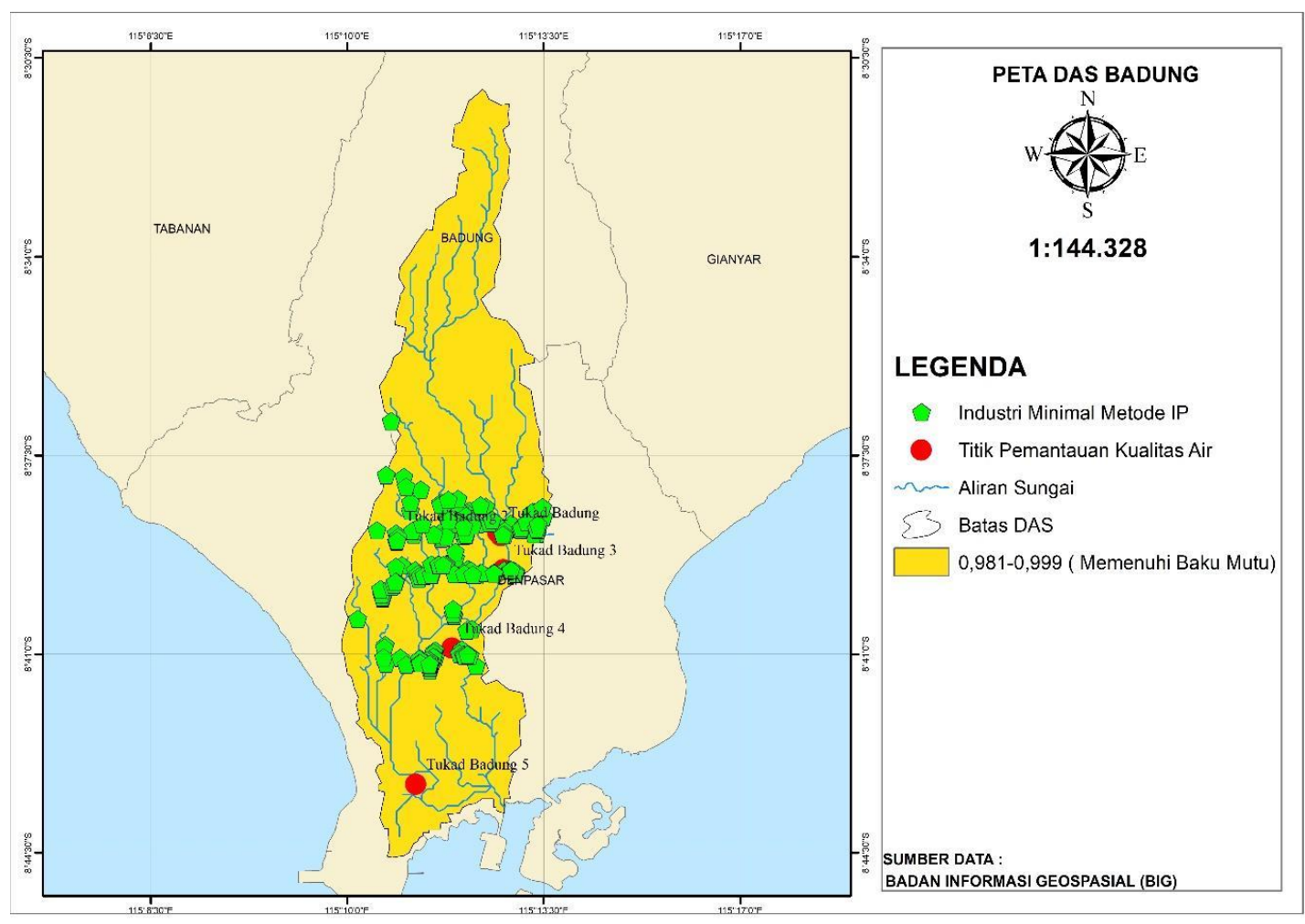

Gambar 8. Pemetaan sebaran kualitas air minimal simulasi 1 metode IP tahun 2019

Pada Gambar 8 disajikan hasil dari metode Kriging yang menghasilkan sebaran kualitas air pada kelima titik pemantauan kualitas air pada kondisi minimal menggunakan metode Indeks Pencemaran dengan nilai sebesar 0.981-0.999 di mana termasuk kategori memenuhi baku mutu dengan jumlah industri sebanyak total 213 industri.

\section{Kesimpulan}

Dari hasil analisis dan simulasi yang telah dilakukan terhadap kualitas air Tukad Badung dapat disimpulkan bahwa nilai indeks kualitas air Tukad Badung dengan menggunakan metode Indeks Pencemaran dan Water Quality Index (WQI) mengalami perubahan yang fluktuatif dari tahun ke tahun. Pada simulasi yang telah dilakukan, didapatkan hasil yang tidak jauh berbeda antara simulasi 1 dan 2 karena nilai indeks kualitas air pada tahun 2019 dan tahun 2020 tidak jauh berbeda, sehingga ketika disimulasikan menggunakan operasi matematika sederhana perkalian silang satu variabel dapat diketahui jika nilai indeks kualitas air sangat mempengaruhi jumlah industri yang diijinkan di titik pemantauan kualitas air DAS Tukad Badung. Dari simulasi ini juga didapatkan bahwa pencemaran yang terjadi pada DAS Tukad Badung disebabkan mayoritas oleh beberapa parameter, seperti kadmium (Cd) yang bersumber dari industri cat dan plastik. Phospat $\left(\mathrm{PO}_{4}^{3-}\right)$ yang bersumber dari kotoran manusia atau hewan, industri, detergen. Sehingga diperlukan kebijakan serta aturan yang tegas dari pemerintah untuk pengendalian lingkungan dan penataan kawasan pada DAS Tukad Badung ini. Untuk itu, studi ini dapat dijadikan rujukan bagi pemerintah untuk pengambilan kebijakan dan pembuatan aturan tersebut.

\section{Ucapan terima kasih}

Ucapan terima kasih disampaikan kepada Bapak Maryadi Utama, ST. M.Si selaku Kepala Balai Wilayah Sungai Bali Penida yang telah mengijinkan penulis untuk meminta data dari Balai 
Wilayah Sungai Bali Penida. Tak lupa juga kepada ibu Dewi Suci Setyowati, ST selaku staf bagian PSDA Balai Wilayah Sungai Bali Penida yang telah memberikan informasi terkait penelitian ini.

\section{Daftar Pustaka}

Altansukh, Ochir, and G. Davaa. 2011. "Application of Index Analysis to Evaluate the Water Quality of the Tuul River in Mongolia." Journal of Water Resource and Protection 03(06): 398-414.

Arsyad, S. 1989. Konservasi Tanah Dan Air. Bogor: IPB Press.

Dinas Lingkungan Hidup dan Kebersihan. 2019. Inventarisasi Sumber-Sumber Pencemar Air Di Kecamatan Denpasar Utara Dan Denpasar Barat. Denpasar: PT. TRILOGI UTAMA.

Hadisantoso, Eko Prabowo et al. 2018. "Pengolahan Limbah Air Wudhu Wanita Dengan Metode Aerasi Dan Adsorpsi Menggunakan Karbon Aktif." al-Kimiya 5(1): 1-6.

Haribowo, Riyanto et al. 2017. "Behavior of Toxicity in River Basins Dominated by Residential Areas." Contemporary Engineering Sciences 10(7): 305-15. www.mhikari.comhttps://doi.org/10.12988/ces.2017.7116 (April 13, 2020).

Haribowo, Riyanto, Very Dermawan, and Nevandria Yudha. 2018. "Application of Artificial Neural Network For Defining The Water Quality in The River." Civil and Environmental Science 001(01): 12-18.

Keputusan Menteri Negara Lingkungan Hidup. 2003. Keputusan Menteri Negara Lingkungan Hidup Nomor 115 Tentang Pedoman Penentuan Status Mutu Air. Jakarta: Menteri Negara Lingkungan Hidup.

Limantara, Lily Montarcih, and Widandi Soetopo. 2014. Statistika Terapan Untuk Teknik Pengairan. Malang: Percetakan CV. Citra Malang.

Mahendra, Made Sudiana et al. 2015. Analisis Air Tukad Badung Di Kota Denpasar. Denpasar.

Peraturan Pemerintah Republik Indonesia. 2011. Peraturan Pemerintah Republik Indonesia Nomor 38 Tahun 2011 Tentang Sungai.

Pramono, Gatot H. 2008. “Akurasi Metode IDW Dan Kriging Untuk Interpolasi Sebaran Sedimen Tersuspensi." Forum Geografi 22(1): 97.

Sasongko, Endar Budi, Endang Widyastuti, and Rawuh Edy Priyono. 2014. "Kajian Kualitas Air Dan Penggunaan Sumur Gali Oleh Masyarakat Di Sekitar Sungai Kaliyasa Kabupaten Cilacap." Jurnal Ilmu Lingkungan 12(2): 72.

Soewarno. 1995. Hidrologi Aplikasi Metode Statistik Untuk Analisa Data Jilid 2. Bandung: NOVA.

Yamashita, H. et al. 2012. "Toxicity Test Using Medaka (Oryzias Latipes) Early Fry and Concentrated Sample Water as an Index of Aquatic Habitat Condition." Environmental Science and Pollution Research 19(7): 2581-94. 